\title{
煩部にみられた多形性腺腽の了例
}

\author{
笠合遠婎・朝合昭人・坂元晴彦 \\ 乙貫典子・神山卓久・中山兑 \\ 檽本等・大埸正亮・小守 昭*
}

\section{Three cases of pleomorphic adenoma of the cheeks}

\author{
Tatsuo Kasakura - Akihito Asakura - Haruhiko Sakamoto \\ Noriko Otozura - Takahisa Kamiyama - Akira Nakayama \\ Hitoshi Hashimoto - Masasuke OвA - Akira Komori*
}

\begin{abstract}
A pleomorphic adenoma is the most common of all salivary gland tumors.
The most frequently affected gland is the parotid in major salivary glands and the palate in minor salivary glands is often observed. Incidences on the cheek, lip, floor of the mouth and tongue are comparatively rare.

The writers experienced three cases of the pleomorphic adenoma originating in the cheeks and report as follows.

All were females who complained of swelling of the buccal mucosa. The masses were indolent, circumscribed, well-demarcated, elastically hard and movable. In all cases, the masses were enucleated from the oral, examinated histopathologically and diagnosed as the pleomorphic adenoma.
\end{abstract}

They were diverse and part calcification was seen in only one case.

The prognosies were excellent.

Key words: Pleomorphic adenoma, minor salivary gland, cheek

\section{緒言}

多形性腺腫は, 上皮性起源の腫湯で腺腫に属すと考え

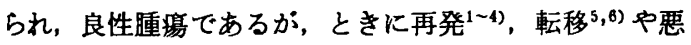
性化》ををすることがあるため，長期の钼察が必要であ 3.

本腫場は，唾液腺腫瘍のなかですっとも頻度が高く，

独協医科大学口腔外科学教室

（主任：朝倉昭人教授）

* 徳島大学药学部口腔病理学教室

（主任：小守 昭教授）

Department of Oral Surgery, Dokkyo University

School of Medicine (Chief: Prof. Akihito Asakura)

* Department of Oral Pathology, Tokushima University School of Dentistry (Chief: Prof. Akira Komori)

受付日：昭和59年11月 15 日
大唾夜腺, 特に耳下腺に多発する。睡液腺では口蓋部 に最も多くみられるが, 頖部、口居, 舌および口底部で は比較的まれである。

今回, われわれは, 頓部に発生した多形性腺腫 3 症例 を経験したので報告する．

症例 1

患 者: 60歳 女性.

初診：昭和55年 8 月回。

主 訴: 左側煩部の腫脹.

既往歴およひ家族歴：特記事項なし。

現病歴: 約 3 年前より左側煩部口腔粘膜に, 大豆大の 腫瘤に気づいたか，無痛性であったため放置、最近にな り腫瘤が增大してきたため当科を受診した。

現 症 : 顔貌は左右非対称, 左側頓部は鵎卵大に腫脹

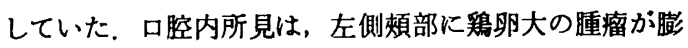
隆しており, 表面は健康な粘膜で被われ, 一部頉粘膜と わずかに痛着がみられたが, 他の周囲組織とは痹着がな く可動性であった（写真 1，2）. 


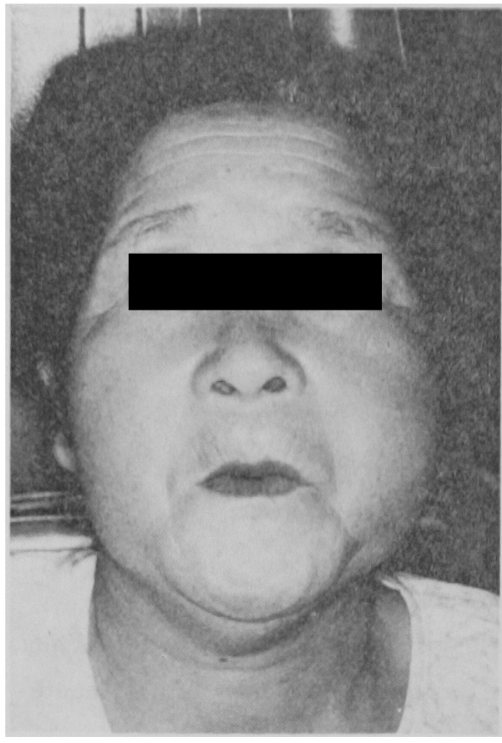

军卉 1 症例 1 顔貌所見

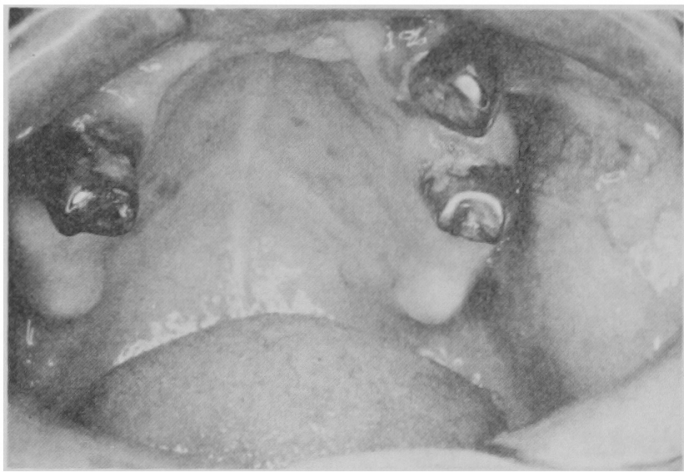

写真 2 症例 1 口腔内所見

X線所見：胸部 $\mathbf{X}$ 線写真に異常はみられなかった。

好置および経過：昭和 55 年 9 月 $\square$ 日，全身麻酔下に $\tau$ ，口腔内より耳下腺開口部の下方に咬合平面に沿って 約 $4 \mathrm{~cm}$ の切開を加えて，周囲より鈍的に䊶離摘出した. 煩粘膜と一部瘦着がみられたが，一塊として磻出でき た，摘出物は被膜に包まれた $3.5 \times 3.5 \times 5.0 \mathrm{~cm}$ の大き さで，割面は灰白色の 充実性であった（写直了）。現在 4 年経過しているが，再発はなく経過は良好である。

病理組織学的所見：腫瘍組織の充実珄の増殖があり， 円形あるいは㮠円形の核を有する多角形の上皮細胞が， 髄様あるいは，胞巣状に增殖し，一部に管腔搆造もみら れる，間質には硝子化が著明て，腫裼組織内には，小さ な管檫を形成し，一部粘液腫様のところるみられること より，多形性腺畽と診断した（写真 4).

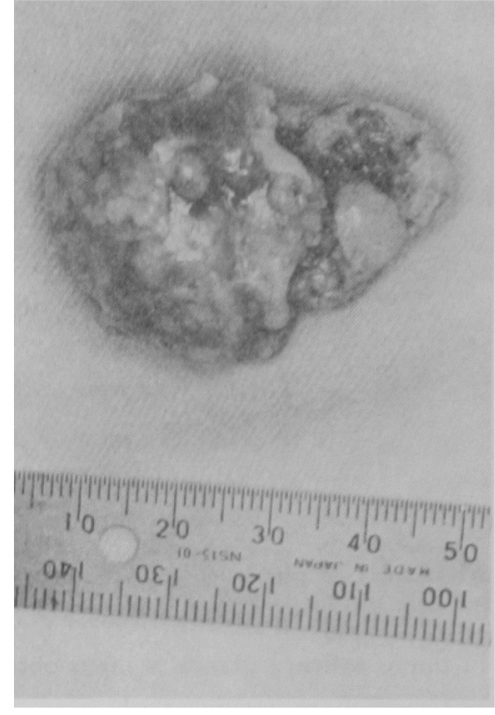

写真 3 症湖 1 摘出物

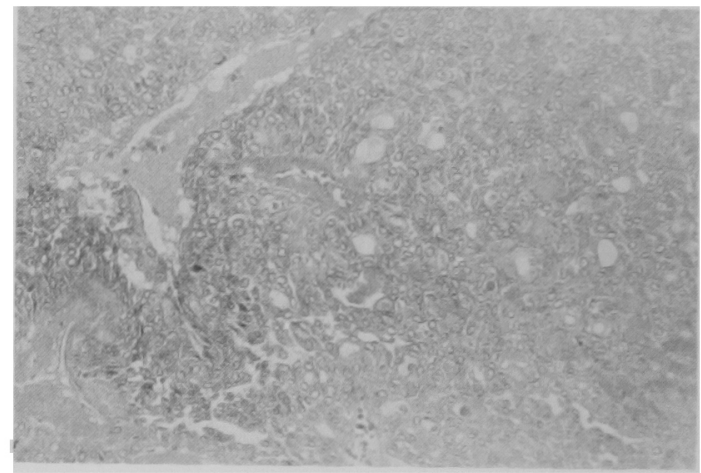

写真 4 症例 $1(\mathrm{H}-\mathrm{E}$ 染色, $\times 100)$

症例 2

患 者: 41 歳 女性.

初 診: 昭和57年 7 月 $⿴$ 日。

主 訴：左側煩部腫脤.

既往歴および家族歴：20年前に肺結核。

現病歴：1 年半前に左侧煩部に小指頭大の腫溜に気つ いたが，自筧症状がないため放膡，1年前より，睡溜が 增大してきたので来院.

現 症：耳下腺前縁部から鼻唇溝にかけて腫脹。鵄卵 大の腫瘤で弾性硬, 境界明瞭, 圧痛および自発痛はな く，周囲組織との癒着はない，䫑下リンパ節は触れない (写直 5，6).

$\mathbf{X}$ 線所見：胸部X線写真では，左右上肺野に肺結核の 治堍を示す石灰化像を認めるが，他は異常所見は認めら れない(写真 7 )。 


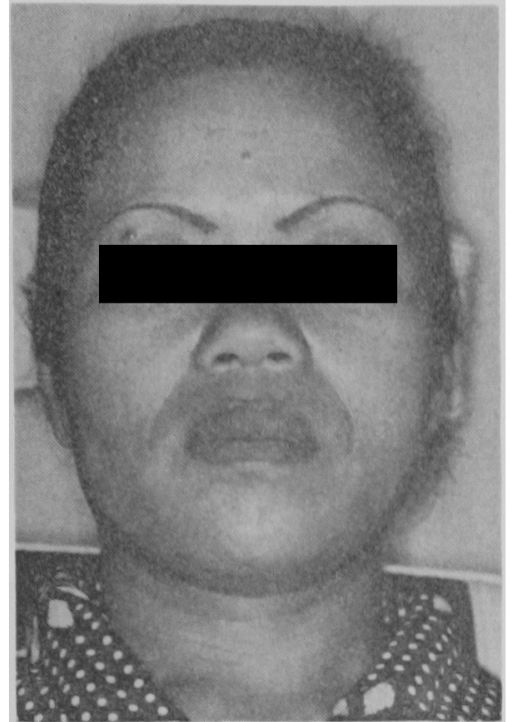

写荤 5 症例 2 顔貌所見

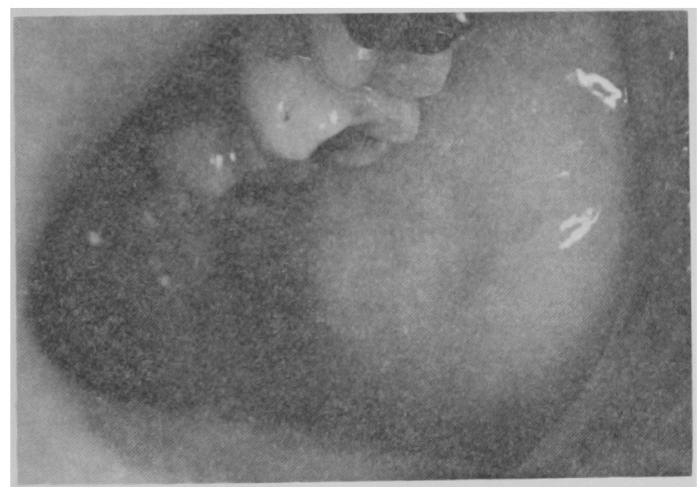

写真 6 症例 2 口腔内所見

処置および経過：昭和57年7月口日，全身麻醉下にて 腫堭摘出術施行. 口腔内より耳下腺開口部下方に切開を

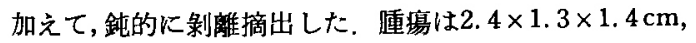
割面は灰白色で充実性 (写真 $8 ， 9$ )。 2 年 2 力月経過 しているが，释過は良好である。

病理組織学的所見: 線維性被膜で囲まれ, 属瘍は全体 に粘液腫様で，この中に多角形あるいは紡鋟形の細胞が 散在している。ところにより，これらの練胞が比較的密 なところもありこれらの部では管腔状構造もみられ る、また，一部には扁平上皮細胞によりなる部るみら れ，硝子化しているところも一部みられるが，軟骨組緎 は明らかではない，以上より，多形性腺腫と診断した (写真10, 11).

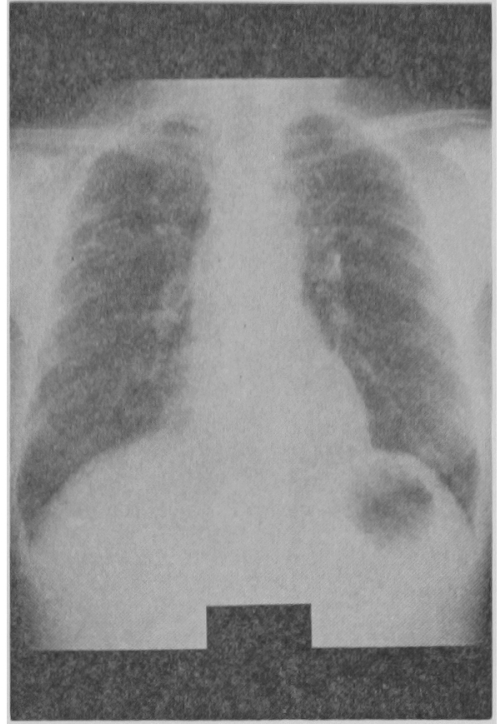

写重 7 症例 2 胸部X線写真

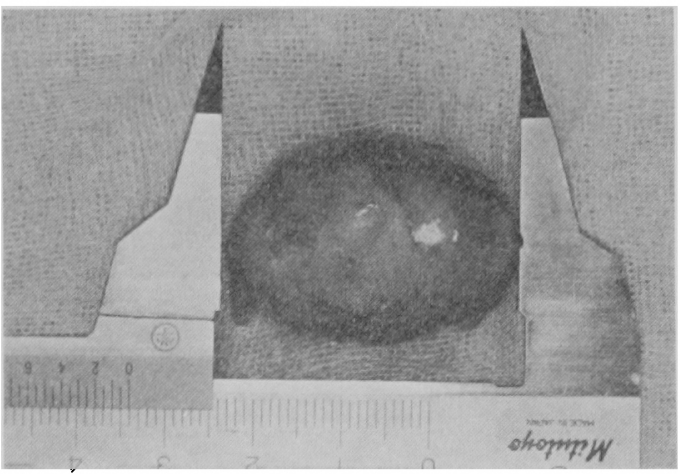

写真 8 症例 2 摘出物

症例 3

患 者: 74藏 女性.

初診：昭和 57 年 12 月日日.

主 訴：左側煩部連脹。

既往歴および家族歴：数年前より高血王症を指摘され るむ放置。

現病歴：10年前より, 左側頓部の嗹瘤に気つくく, 無 痛性のため放圆。歯科治療のため近医受診し，腄瘤を指 摘され当科紹介され来院.

現 症：顔貌左右非対称，口腔内所見では，表面が健 康な粘膜で被われた，拇指頭大の腫瘁が触れ，境界は明 瞭で周团組織とは癒着がなく可動性である（写真 12）。

$\mathbf{X}$ 線所見：胸部X線では特に異常がなく、オルンパン トモグラムで，頼部の腫唃相当部に円形の石灰化像が認 


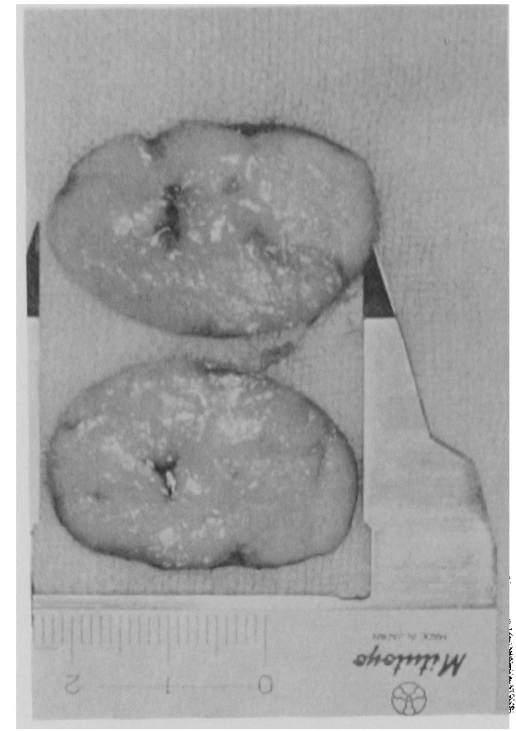

写真 9 症例 2 摘出物割面

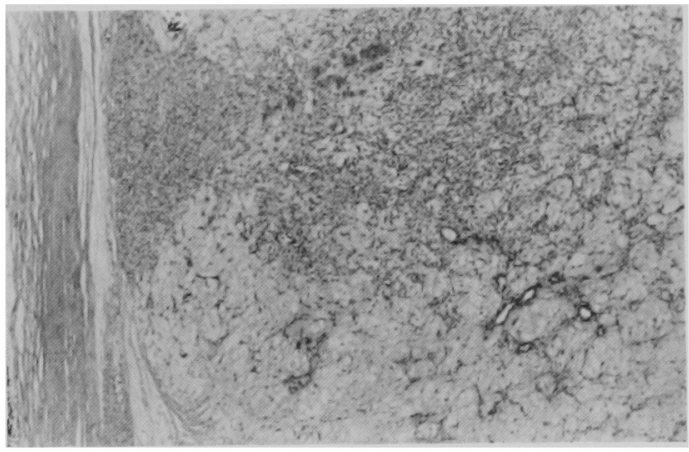

写高 10 症例 $2(\mathrm{H}-\mathrm{E}$ 染色， $\times 40)$

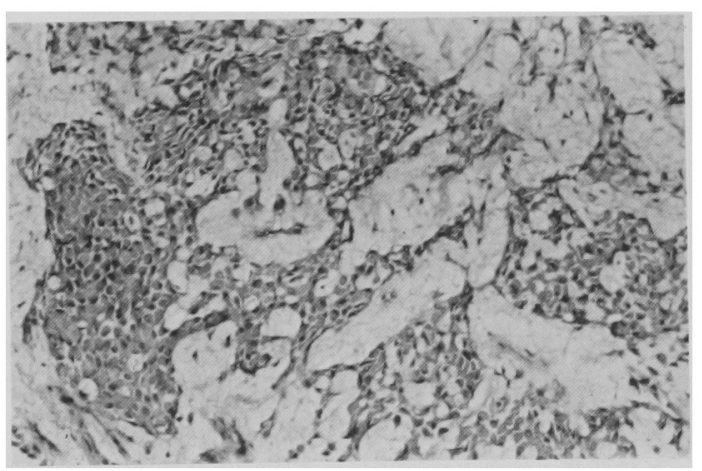

写高 11 症例 $2(\mathrm{H}-\mathrm{E}$ 染色, × 100)

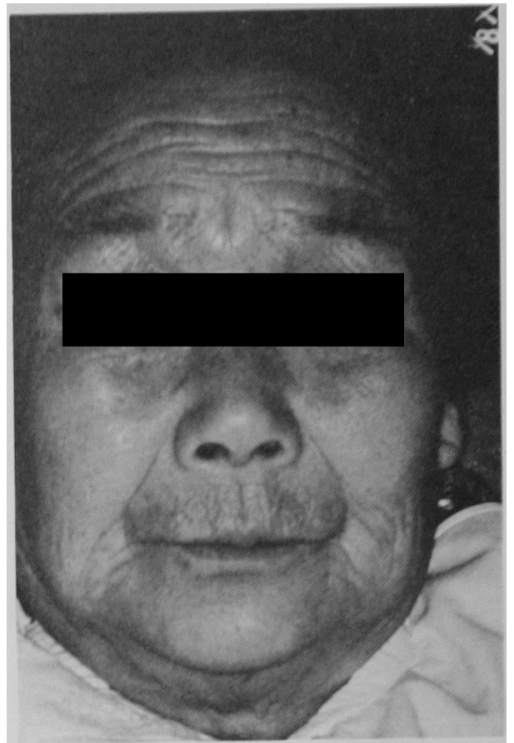

写素 12 症例 3 硕貌所見

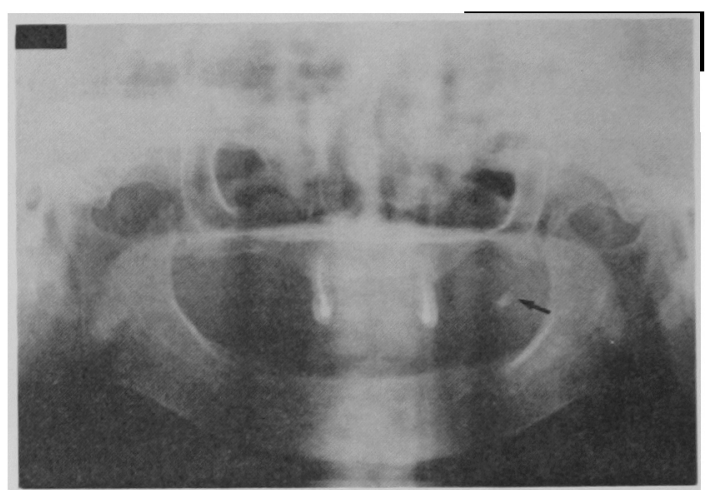

写真 13 症例 3 オルソパントグラム

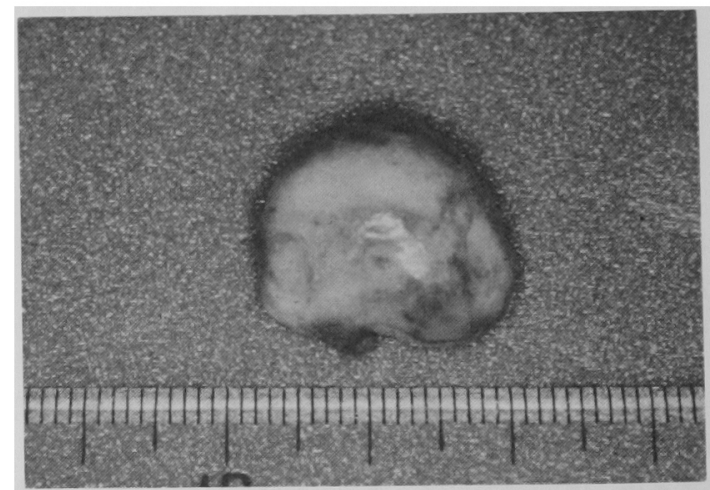

写重 14 症例 3 摘出物 


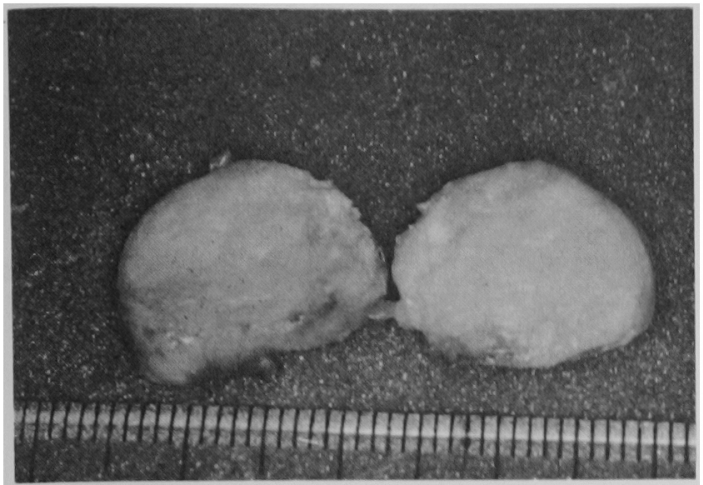

写重 15 症例 3 摘出物制面

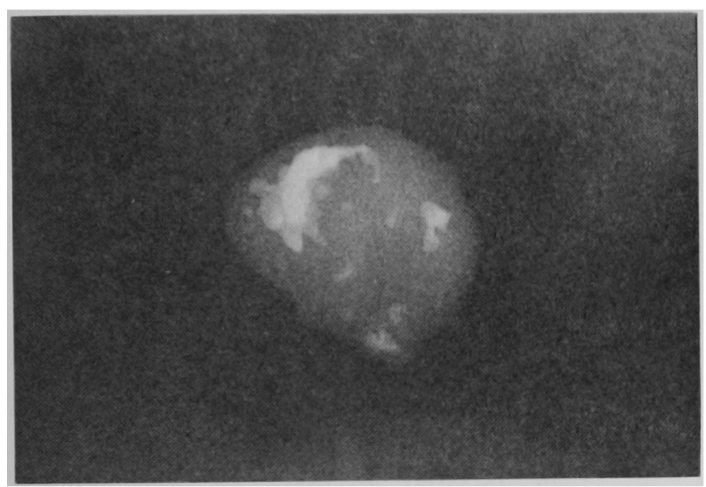

写重 16 症例 3 摘出物X線写真

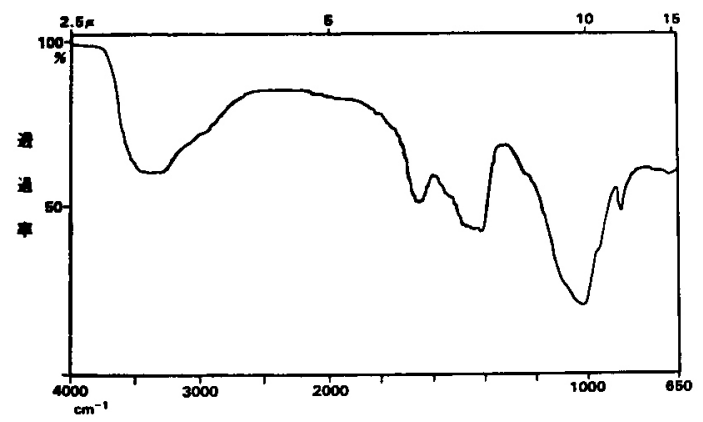

图 1 症例 3 摘出物赤外線吸収スベクトル

められる(写真13).

処置および経過：昭和57年12月口日，全身麻醉下にて 左側煩部腫瘤摘出術施行。腔内より耳下腺開口部下方 に切開を加えて，剥離摘出した，摘出物は被膜に包をれ た， $2.2 \times 1.8 \times 1.8 \mathrm{~cm}$ の尰瘤で，割面は灰白色で一部 石灰化を伴っていた（写真 14，15，16）. 赤外線吸収 ベクトルにより，石灰化物の主成分はりン酸カルシウ ムであり，EPMA に上る元素分析では， Ca， P, Zn, Si

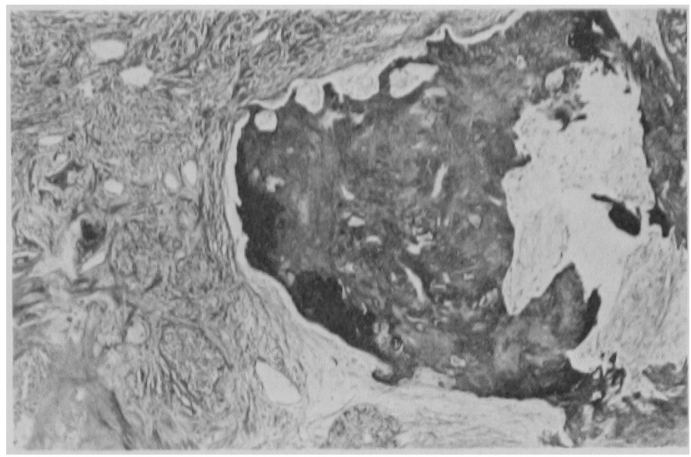

军真 17 症例 3（H-E染色， X40)

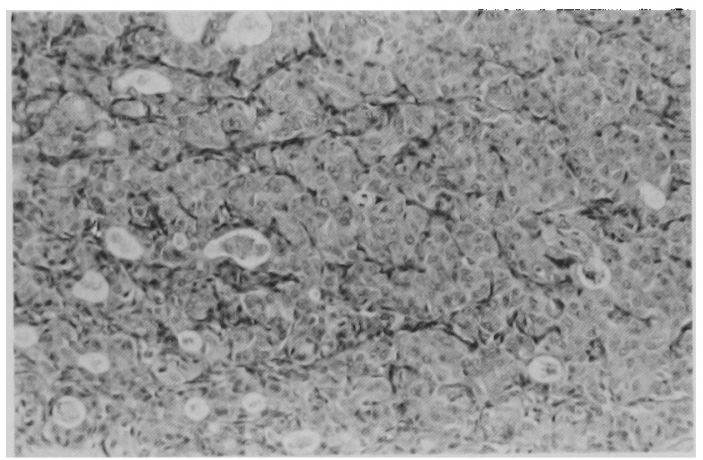

写真 18 症例 $3(\mathrm{H}-\mathrm{E}$ 染色， $\times 100)$

と微量の $\mathrm{Fe}, \mathrm{Mg}$ が恰出された（图 1). 現在 1 年10か 月経過しているが，再発るなく経過良好である。

病理租織学的所見：周囲が線維性被膜で囲まれ，腫瘍 組織は大部分が高度に硝子化しており，その一部に不規 則な石灰化もみられる。結節状の腫湯組織の主として，

周辺部に細胞成分が認められる。この腫場細胞は円形あ るいは棈円形の核を有する多面形の細胞が小胞巣状をた は腺管状に比較的密に增殖していて, 異型性は認められ ない，畽湯細胞はところにより空胞状で，ムチカルミン 染色に陽性を示するのるみられる，粘液腫様または軟骨 様の部分は認められない，以上より多形性腺隀と猃断し た（写真 17，18）.

\section{考察}

多形性腺腫は，唾液腺腫湯のなかでもっとも頻度が高

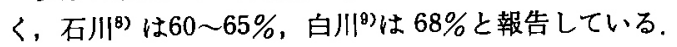

一般に大部分は，大唾夜腺由来であるが，小喠液腺に特 ける発生頻度について, Garcelon ${ }^{10)}$ は $7 \%$, Hendrick ${ }^{11)}$ は17\%，Krolls ら ${ }^{122}$ は11\%と低い值を示している。 た，小碃液腺のなかで煩部における発生頻度について, 
Fine $5^{2)} 16 \%$, Chaudhrys) 5.7\%, Hendrick ${ }^{(1)} 3.6 \%$, Frable 5) $13.3 \%$, Soskolre $5^{18)} 15.4 \%$, Pogrel ${ }^{14)} 16$

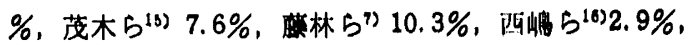
森本ら ${ }^{17)} 8.8 \%$ ，白川早3.8\%といずれも低い檤で，比 較的まれなことを報告している。

頓部小唾液腺に発生した多形性腺婳の症例般告 ${ }^{18 \text {-8B) }}$ あ少なく、いちれるまれなるを付記している。

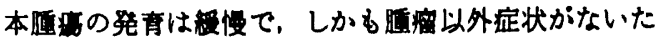
め，初発上り長い年月を経過して受脸する谒合が多い。

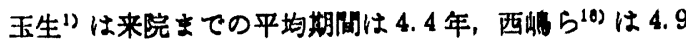
年, Hendrick ${ }^{11)}$ は平均 5.2 年といずれる長く、また，

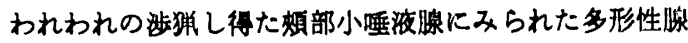
遇の症例報告では，1か月より取長 33 年で平均すると 6.9 年でかなり長期にわたり放娄されている.

本缠瘦の治療法としては，外科的切除が一般に行われ

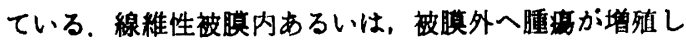

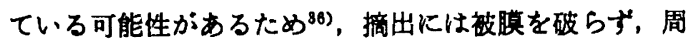
囲健康組織を含めて切除することが望ましいと考えられ ているが，頉部においては顔面神経の損做を照念し，可 及的に切除せさるを得ない.

再発に関しては，小唾液腺では比較的まれと专われて おり，玉生方は29 例中 2 例， Fine') らは再発なし， Chaudhry $5^{\text {) }}$ は30例中 2 例, Frable ら"は42例中 2 例 の再発を報告しているか;，山本ら ${ }^{87)}$ は煩部小喠液腺に発 生した多形性腺腫で初回手術後15年後に再発した症例を 報告しており，長期の钼察が必要之思われる，再発の原

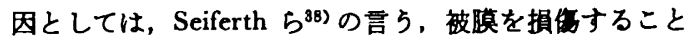
や尰弱の取り残しが考えられるか，組織型が再発に成係 することす指摘されておりり，Naeim ら ずれる細胞成分の少ない粘液棣間質を持つものに再発が 多いと報告している，症例 3 は細胞成分が少ない再発の 多い type に属すると考えられ，今後の十分なる経過観 察が必要と思われる.

多形性腺腫では，ごくまれに転移をきたした報告すあ ろ. Gerughty らうは 35 例中 3 例に肺とリンパ節への枟 移がみら，そのうち2 例はさらに骨へ転移していたと 報告し，Chen ${ }^{8)}$ は仙骨への転移例を報告している.

覀性化に関しては，藤林ら7) か331例中 2 例に悪性化を

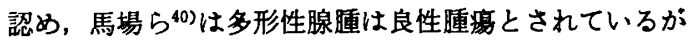
low grade malignant な腫痬として扱うことを述べてい Ђ.

多形性腺腫における石灰化の報告はまれであり, Dyke ら (1)は耳下腺に発生した多形性腺庫においてシュウ酸カ ルシウムの沈着がみられた症例を報告している. Gerughty $5^{5)}$ は悪性多形性腺腫 25 例中 8 例に石灰化を認め, Brown ${ }^{42)}$, Grymer 5 ${ }^{43)}$ も石灰化物を含む覀性多形性腺 腫を報告し, 石灰化と悪性化の関連が示唆される. われ われの症例においても石灰化物を含む多形性腺腫があ り，今後の注意深い経過観察が必要と思われる。

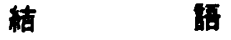

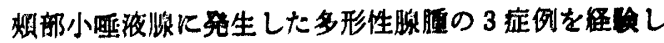

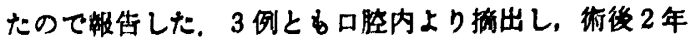

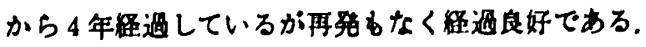

本編文の要目は，昭和59年10月20日第 130 回日本口䁙 外科学会的束地力会に打いて甡表した。

\section{引用文 部}

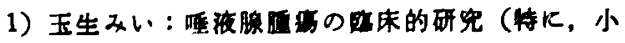

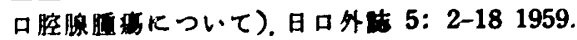

2) Fine, G., Marshall, R.B., et al.: Tumors of the minor salivary glands. Cancer 13: 6536691960.

3) Chaudhry, A.P., Vickers, R.A., et al.: Intra oral minor salivary gland tumors. An analysis of 1414 cases. OS OM OP 14: 1194-1226 1961.

4) Frable, W.J. and Elzay, R.P.: Tumors of minor salivary glands. A report of 73 cases. Cancer 25: 932-941 1970.

5) Gerughty, R.M., Scofield, H.H., et al.: Malignant mixed tumors of salivary gland origin. Cancer 24: 471-486 1969.

6) Chen, K.T.K.: Metastasizing pleomorphic adenoma of the salivary gland. Cancer 42: 2407-2411 1978.

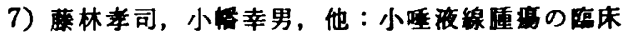
的研究。只科誌 21：901-928 1972.

8）石川梧朗監修：口腔病理学 II. 第 2 刷. 永末書 店, 京都, 1984 718-728頁.

9）白川正順：喠液腺腫境の医床病理学的研究. 蓦 医誌 95: 1402-1419 1980.

10) Garcelon, G.G.: Salivary gland tumors. Management and results. Arch Surg 78: 12-16 1959.

11) Hendrick, J.W.: The treatment of tumors of minor salivary glands. Surg Gynecol Obstet 118: 101-111 1964.

12) Krolls, S.O. and Hicks, J.L.: Mixed tumors of the lower lip. OS OM OP 35: 212-217 1973.

13) Soskolre, A., Sela, J., et al.: Minor salivary gland tumors.: a survey of 64 cases. J Oral Surg 31: 528-531 1973.

14) Pogrel, M.A.: Tumors of the salivary gland tumors.: A histological and clinical review. Br J Oral Surg 17: 47-56 1979.

15）茂木克俊, 大烟值嘈，他：㛲部小唾液腺飞原発 した良性多形性腺腫の 5 例。口科誌 19：2222291970. 
16）西鸠克己，日高貫蔽，他：わが室における低

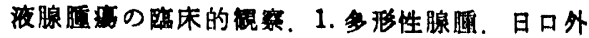
誌 19: 20-24 1973.

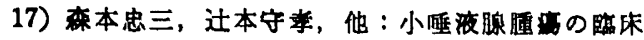

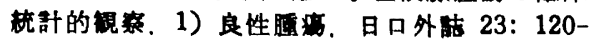
1251977.

18）玉井健三，河合宏一，他：煩部小唯液滕儿原発 した良性多形性腺脾の 1 例。日口外誌 19：81831973.

19）量田裕介，志水和弘，他：媔部多形性腺脂の1 例. 城莐大杞贾 6:425-427 1977.

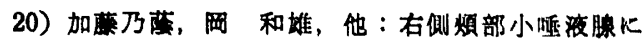
原発した多形性腺尰の 1 症例. 佼正医誌 2: 50531977.

21）深谷忠芳，古筫一郎，他：煩部に発生した多形

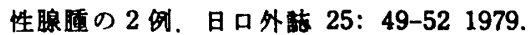

22）坂元暏度，朝合昭人，他：煩部に存在した多形 性腺腫の1测. 日口外誌 27：46-49 1981.

23）黑川英婎，鳥越義広，他：煩部に発現した多形 性腺腫の1例。九州粎会誌 36：358-366 1982.

24）高木澄雄，大㴖㳯一郎，他：煩部比発生した多 形性腺腫の 1 例. 日口外誌 28: 132-135 1982.

25）河野信彦, 井敏昭：煩部に発生した多形性眿 尰の 1 例。 日口外誌 29: 148-150 1983.

26）宇沢俊一, 白川正順，他：煩部比発生した多形 生腺漣の 1 例。日口外誌 29：216-220 1983.

27) Mardirossian, G. and Najjar, T.A.: Mixed tumor of minor salivary gland-An unusual case. J Oral Med 36: 4-6 1981.

28）時田優，丸谷雅晴，他：頓粘膜に発生した多 形性腺腫の 2 例 (抄). 口科誌 25: 5261976.

29）阿部洋一郎，敛芳夫，他：煩部小唾液に発生 した良性多形性腺腫の 2 症例（抄）. 久ちのく 齿学誌 8: 341977.

30）伊藤一晴，千葉良人，他：小唾液腺に原発した 多形性腺腫の 2 例 (抄). 日外誌 23: 741 1977.

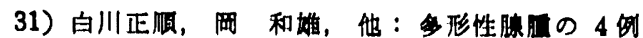
（抄）。口外誌 24:86 1978 .

32）吉田亭，泉広次，他：烦部粘㬺下に発生し

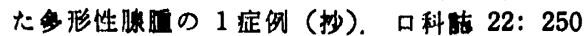
1973.

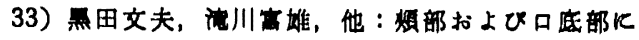
生した多形性䖪近の 2 侧（抄），日口外誌 28: 801982.

34)三角洋介，矢离㭲子，他：煩部に発生した多形 性腺膄の1例 (抄)。口科洁 31：468 1982.

35）椐一，白数力也，他：煩粘䐜に発生した主 性多形性腺脜の 1 例 (抄)，日口外结 28：186 1982.

36）金城 小, 小池正夫, 他：口腔内に生した多形

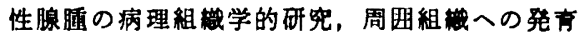
状態について。日外誌 28: 34-38 1982.

37）山本悦秀, 小浜源郁, 他: 初回手術の15年後比 再発が確認された頪部小湩液腺原発多形性腺腫 の 1 例. 日外誌 28: 61-65 1982.

38) Seiferth, L.B., Kleinsser, O., 他：喠液腺腫瘍

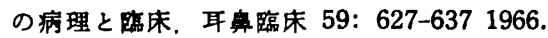

39) Naeim, F., Forseberg, M.I., et al.: Mixed tumors of the salivary glands. Growth pattern and recurrence. Arch Pathol Lad Med 100: 271-275 1976.

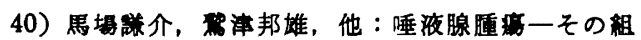

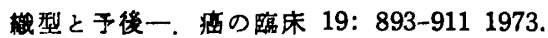

41) Dyke, P.C., Hajdn, S.I., et al.: Mixed tumor of parotid containing calcium oxalate crystals. Arch Path 91: 89-92 1971.

42) Brown, J.M.: An unusual salivary gland calculus. Med J Aust 2: 877-878 1970.

43) Grymer, L.F., Jørgensen., K., et al.: Carcinoma in a calcified pleomorphic adenoma of the submandibular gland. J Laryngol Otol 96: 373-376 1982. 